\title{
MS-275 synergistically enhances the growth inhibitory effects of RAMBA VN/66-I in hormone-insensitive PC-3 prostate cancer cells and tumours
}

\author{
A Khandelwal', LK Gediya' and VCO Njar*,1,2 \\ 'Department of Pharmacology and Experimental Therapeutics, University of Maryland School of Medicine, 655 West Baltimore Street, Baltimore, MD \\ 2I 201 - I 559, USA; ${ }^{2}$ Marlene and Stewart Greenebaum Cancer Center, University of Maryland School of Medicine, Baltimore, MD 21 I 20 I- I 559 , USA
}

Combining drugs, which target different signalling pathways, often decreases adverse side effects while increasing the efficacy of treatment. The objective of our study was to determine if the combination of our novel atypical retinoic acid metabolism-blocking agent (RAMBA) VN/66-I and a promising histone deacetylase inhibitor $\mathrm{N}$-(2-aminophenyl)4-[N-(pyridine-3-yl-methoxycarbonyl)aminomethyl]benzamide (MS-275) would show enhanced antineoplastic activity on human PC-3 prostate cancer cells/ tumours and also to decipher the molecular mechanisms of action. The combination of VN/66-I + MS-275 was found to be synergistic in inhibiting PC-3 cell growth, caused cell cytostaticity/cytotoxicity and induced marked G2/M phase arrest and apoptosis. In mice with well-established PC-3 tumours, VN/66-I $\left(5\right.$ and $10 \mathrm{mg} \mathrm{kg}^{-1}$ day $\left.{ }^{-1}\right)$ caused significant suppression of tumour growth compared with mice receiving vehicle alone. Furthermore, treatment with VN/66-I $\left(10 \mathrm{mg} \mathrm{kg}{ }^{-1} \mathrm{day}^{-1}\right)+\mathrm{MS}-275$ $\left(2.5 \mathrm{mg} \mathrm{kg}^{-1} \mathrm{day}^{-1}\right)$ for 18 days resulted in an $85 \%$ reduction in final mean tumour volume compared with control and was more effective than either agent alone. Mechanistic studies indicated that treatment of PC-3 cells/tumours with VN/66-I + MS-275 caused DNA damage (upregulation of $\gamma \mathrm{H} 2 \mathrm{AX}$ ), hyperacetylation of histones $\mathrm{H} 3$ and $\mathrm{H} 4$, upregulation of retinoic acid receptor- $\beta$, p2I WAFI/CIPI, E-cadherin, and Bad and downregulation of Bcl-2. These data suggest that the mechanism of action of the combination of agents is DNA damage-induced p2I activation, resulting in inhibition of the Cdc2/cyclin B complex and accumulation of cells in G2/M phase. In addition, the combination caused modulation and induction of apoptosis. These results suggest that VN/66-I or its combination with MS-275 may be a novel therapy for the treatment of prostate carcinoma.

British Journal of Cancer (2008) 98, 1234-1243. doi: 10.1038/sj.bjc.6604295 www.bjcancer.com

Published online 18 March 2008

(c) 2008 Cancer Research UK

Keywords: prostate cancer (PCa); retinoic acid metabolism-blocking agents (RAMBAs); histone deacetylase inhibitors (HDACls); VN/66-I; MS-275; combination therapy

Prostate cancer $(\mathrm{PCa})$ is the most frequently diagnosed cancer in American men with an estimated 218890 new cases of the disease in 2007 (Jemal et al, 2007). Since PCa is one of the leading causes of deaths worldwide, there is an urgent need to identify effective agents against this disease. Retinoids, rexinoids, retinoid-related molecules (RRMs) and histone deacetylase inhibitors (HDACIs) have shown promising biological activities as single agents in several preclinical studies of both haematological and solid malignancies (Altucci and Gronemeyer, 2001; Lindemann et al, 2004; Bolden et al, 2006; Njar et al, 2006a). Because of the heterogeneous nature of $\mathrm{PCa}$, we hypothesise that agents/ combination of agents affecting various pathways involved in PCa growth and survival may be advantageous.

* Correspondence: Dr VCO Njar, University of Maryland School of Medicine, Department of Pharmacology and Experimental Therapeutics, Baltimore, MD, 2120 I- 1559, USA; E-mail: vnjar00 I@umaryland.edu Received 5 November 2007; revised 14 February 2008; accepted 19 February 2008; published online 18 March 2008
It is well noted that ATRA (all-trans retinoic acid), the most active metabolite of vitamin $\mathrm{A}$ is required for the appropriate differentiation of normal human prostate epithelial cells (Sonneveld et al, 1998). All-trans retinoic acid undergoes cytochrome P450 metabolism to form inactive polar metabolites (Njar et al, 2006b). The metabolism of ATRA by CYP enzymes (particularly by CYP26) and dysregulation of gene expression contribute to the cancerous phenotype. Treatment of disorders with ATRA often leads to the development of resistance and is toxic (Freemantle et al, 2003).

In attempts to overcome retinoid resistance in cancer therapy (Freemantle et al, 2003), our group and others have developed several retinoic acid metabolism-blocking agents (RAMBAs) that are currently being investigated in several pre-clinical models of a variety of cancers and dermatological diseases (Njar et al, 2006b). Our RAMBAs, however, based on the retinoid scaffold are considered 'atypical RAMBAs', because they are also endowed with multiple anticancer activities. On the basis of several studies in our lab, it is now evident that the anticancer activities of our RAMBAs cannot be explained by inhibition of ATRA metabolism alone (Patel et al, 2004, 2007b; Gediya et al, 2005; 
A<smiles>CC1=C(/C=C/C(C)=C/C=C/C(C)=C/C(=O)Nc2ccc(O)cc2)C(C)(C)CCC1n1ccnc1</smiles>

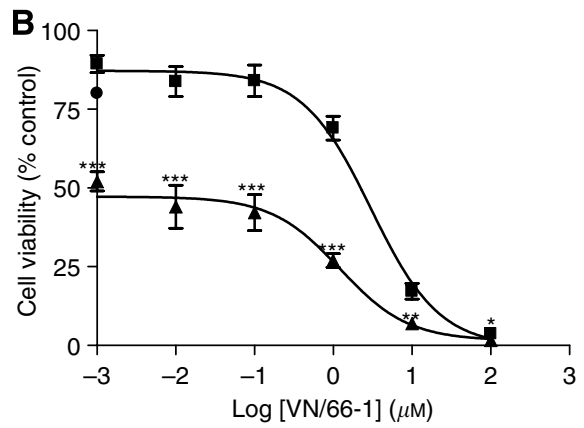<smiles>CS(=O)(=O)c1ccc(CNC(=O)OCc2cccnc2)cc1</smiles>

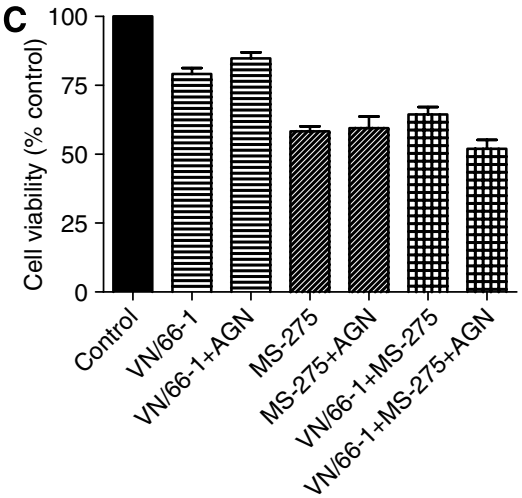

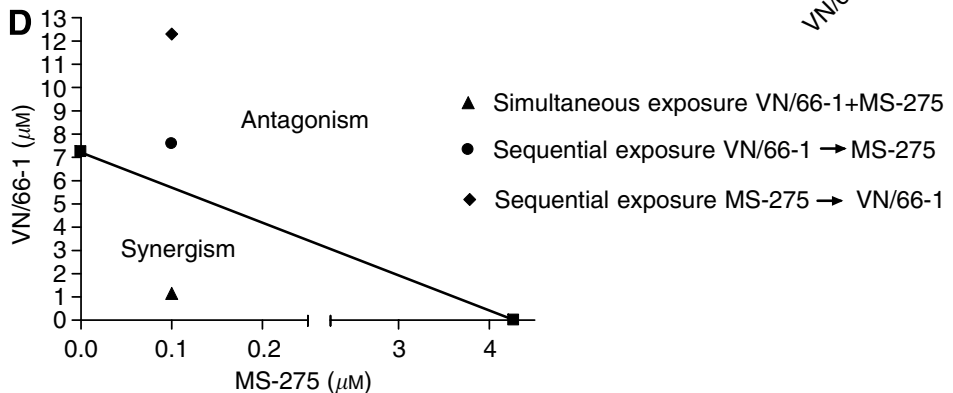

Figure I (A) Chemical structures of RAMBA, VN/66-I and HDAC inhibitor, MS-275. (B) Dose-response curve of VN/66-I alone and the combination of VN/66-I and MS-275 (simultaneous treatment) in PC-3 cells. - denotes various concentrations of VN/66-I alone; $\boldsymbol{\Delta}$ denotes VN/66-I at various concentrations plus $0.1 \mu \mathrm{M}$ of MS-275; - shows the effect of $0.1 \mu \mathrm{M}$ MS-275 alone. $* * * * P<0.005 ; * * P<0.01$; * $P<0.05$ ( $t$-test). (C) The effect of AGN I93I09 (abbreviated AGN), a pan-RAR antagonist on cell viability (simultaneous treatment). PC-3 cells were treated with I $\mu \mathrm{M}$ VN/66-I and/or $0.1 \mu \mathrm{M}$ MS-275, and 0.1 $\mu \mathrm{M}$ AGN 193I09. $* * * * P<0.000$ I (t-test). Data are mean ( \pm s.e.) of at least three independent experiments (B and C). (D) Isobologram analysis of PC-3 cell growth inhibition by VN/66-I and MS-275 simultaneously and sequentially. The $\mathrm{IC}_{75}$ values of each drug are plotted on the axes; the solid line represents the additive effect, while the points represent the concentrations of each compound resulting in $75 \%$ growth inhibition. Arrow indicates sequence of treatment.

Belosay et al, 2006; Huynh et al, 2006). We recently examined the growth inhibitory effects of one of our lead atypical RAMBAs VN/ 66-1 (Figure 1A) in combination with clinically used suberoylanilide hydroxamic acid (SAHA, a HDACI) on the androgen receptor-positive human prostate LNCaP cell line (Gediya et al, 2005). An additive growth inhibitory effect was observed. When tested against other potent RAMBAs and ATRA, VN/66-1 was found to possess the most favourable pharmacokinetic properties in mice and was relatively non-toxic (Patel et al, 2007a). This promising compound may also be effective in hormone-refractory PCa models.

Histone acetyltransferase and histone deacetylase (HDAC) have opposing effect on transcription (Kuo and Allis, 1998; Ito and Adcock, 2002). Often, DNA methylation and histone deacetylation of tumour suppressor genes occur in many human cancers, leading to suppression of function of these genes thereby conferring a growth advantage for the tumour cells (Robertson and Jones, 2000; Macaluso and Giordano, 2004). Indeed, it has been demonstrated that the expression and activity of HDAC1 are upregulated (two- to four-fold) in PCa compared to benign prostatic hyperplasia (Patra et al, 2001). Histone deacetylase inhibitors, such as SAHA, and $\mathrm{N}$-(2-aminophenyl)4-[ $\mathrm{N}$-(pyridine-3-yl-methoxy-carbonyl)aminomethyl] benzamide (MS-275) can directly interact with the HDAC enzymes at the catalytic site and inhibit their function (Marks et al, 2000; Insinga et al, 2005; Bolden et al, 2006). This leads to acetylation of histones, which opens up the chromatin structure allowing transcription of antigrowth and proapoptotic genes to occur. It should be noted that MS-275 is now in phase I/II clinical trials for various solid tumours and haematological malignancies (Hess-Stumpp et al, 2007).

Histone deacetylase inhibitors have been reported to have growth inhibitory activities in PCa models both in vitro and in vivo (Butler et al, 2000; Nakayama et al, 2001; Gediya et al, 2005). In addition, HDACIs when combined with retinoids (e.g., ATRA, 9-cis retinoic acid (9-CRA) or 13-cis-retinoic acid (13-CRA)) display enhanced (additive) anticancer activities (Pili et al, 2001; Gediya et al, 2005; Qian et al, 2005, 2007). However, combination antiproliferative studies with the well-known synthetic retinoid, $\mathrm{N}$-(4-hydroxyphenyl)retinamide, (4-HPR) have produced conflicting results. $\mathrm{Gu}$ et al (2006) clearly demonstrated enhanced cytotoxic effects with the combination of 4-HPR or other retinoids and HDACIs, whereas Kuefer et al (2007) reported that sodium butyrate and 4-HPR administered together antagonise the effects of each other. Nevertheless, these studies suggest that combinations that include retinoids and HDACIs may have a greater therapeutic action than treatment with either agent alone.

It is well established that combining drugs, which target different signalling pathways, can lessen adverse side effects while increasing the efficacy of treatment (Bevins and Zimmer, 2005; Verheul et al, 2007). The objective of our study was to determine if 
the combination of VN/66-1 and MS-275 would show enhanced (additive or synergistic) antineoplastic activity on hormoneinsensitive human PC-3 PCa cells and to decipher the molecular mechanisms of action. In the present report, we describe a synergistic inhibitory effect of MS-275 and our atypical RAMBA VN/66-1 on the growth of PC-3 cells, and we also describe a synergistic inhibitory effect of MS-275 + VN/66-1 administration on the growth of well-established PC-3 tumours in a xenograft model. The antiproliferative effects of these agents alone and in combination are due to DNA damage-induced modulation of cell cycle regulatory proteins including $\mathrm{p} 21^{\mathrm{WAF} 1 / \mathrm{CIP} 1}$ resulting in $\mathrm{G} 2 / \mathrm{M}$ cell cycle arrest and induction of apoptosis via the mitochondrial pathway. Furthermore, we show that these agents, alone or in combination, exert their effect on cell growth via retinoid receptorindependent mechanisms. The novelty of this work arises from that fact that it is the first mechanistic report of a RAMBA in combination with an HDACI as a therapeutic for any disorder including cancer.

\section{MATERIALS AND METHODS}

\section{Chemicals and reagents}

ATRA was purchased from LKT Laboratories Inc. (St Paul, MN, USA), while VN/66-1 and MS-275 were synthesised in our laboratory. AGN193109 was kindly provided by Dr Dianne Soprano, Temple University, Philadelphia, PA, USA.

\section{Cell culture}

The PC-3 (hormone-insensitive PCa) cell line was obtained from American Type Culture Collection (Rockville, MD, USA). C-81 cells were obtained from the lab of Dr Anne Hamburger and PC3AR cells from the lab of Dr Yun Qiu both at the University of Maryland School of Medicine. Cells were maintained in RPMI 1640 medium supplemented with $10 \%$ fetal bovine serum (FBS) (Atlanta Biologicals, Lawrenceville, GA, USA) and $1 \%$ penicillin/streptomycin. Cells were grown as a monolayer in T75 or T150 tissue culture flasks in a humidified incubator $\left(5 \% \mathrm{CO}_{2}, 95 \%\right.$ air $)$ at $37^{\circ} \mathrm{C}$.

\section{Cell growth inhibition (MTT colorimetric assay)}

PC-3 cells were seeded in 24- or 96-well plates (Corning Costar) at a density of $2 \times 10^{4}$ cells per well ( 24 wells) or $2 \times 10^{3}$ cells per well (96 wells). Cells were allowed to adhere to the plate for $24 \mathrm{~h}$ and then treated with various concentrations of VN/66-1 or MS-275 dissolved in $95 \% \mathrm{EtOH}$ and $10 \% \mathrm{DMSO} / 90 \% \mathrm{EtOH}$, respectively. Cells were treated for 5 days with renewal of test compound and media on day 3. On the fifth day, medium was renewed and MTT (3-(4,5-dimethylthiazol-2-yl)-2,5-diphenyl-2H-tetrazolium bromide) (Sigma, St Louis, MO, USA) solution ( $0.5 \mathrm{mg}$ MTT per $\mathrm{ml}$ of media) was added to the medium such that the ratio of MTT: medium was $1: 10$. The cells were incubated with MTT for $2.5 \mathrm{~h}$. The medium was then aspirated and DMSO was added to solubilise the violet MTT-formazan product. The absorbance at $560 \mathrm{~nm}$ was measured by spectrophotometry (Victor 1420 multilabel counter, Wallac, Perkin Elmer, Waltham, MA, USA). For sequential treatment experiments, cells were treated with the first agent for $48 \mathrm{~h}$, washed and treated with the second agent for another $48 \mathrm{~h}$ after which the assay was carried out as described above. Triplicates were carried out for each concentration and experiments were independently repeated a minimum of three times. Results are expressed as percentage of viable cells in the vehicle-treated control wells. $\mathrm{IC}_{50}$ values were calculated by nonlinear regression analysis using GraphPad Prism 4.0 (GraphPad Software, San Diego, CA, USA).

\section{Assessment of synergism, additivity or antagonism}

The level of interaction (synergistic, additive or antagonistic) between VN/66-1 and MS-275 was evaluated as described previously (Chou et al, 1993). Synergism, additivity or antagonism was quantified by determining the combination index (CI), where $\mathrm{CI}<1, \mathrm{CI}=1$, and $\mathrm{CI}>1$ indicate a synergistic, additive or antagonistic effect, respectively. Based on the classic isobologram, the CI was calculated by using the following equation:

$$
\mathrm{CI}=\left[(\mathrm{D})_{1} /\left(\mathrm{D}_{\mathrm{x}}\right)_{1}\right]+\left[(\mathrm{D})_{2} /\left(\mathrm{D}_{\mathrm{x}}\right)_{2}\right]
$$

At the $75 \%$ inhibition level, $\left(D_{x}\right)_{1}$ and $\left(D_{x}\right)_{2}$ are the concentrations of $\mathrm{VN} / 66-1$ and MS-275, respectively, which induce a $75 \%$ inhibition in cell growth. (D) 1 and (D) 2 are the concentrations of VN/66-1 and MS-275, which also inhibit cell growth by $75 \%$ (as compared with single agents alone).

\section{Cell cycle analysis}

Cells were plated in T-75 flasks containing complete RPMI 1640 medium for $24 \mathrm{~h}$. Cells were serum starved after washing with phosphate-buffered saline (PBS) and incubating with RPMI 1640 (minus phenol red) with $0.2 \%$ FBS for $48 \mathrm{~h}$. Under these conditions, cells were arrested in the G0/G1 phase as determined by flow cytometry. Cells were then stimulated by the addition of complete RMPI 1640 medium containing 10\% FBS. Cells were treated with VN/66-1 or MS-275 for various times, washed with PBS, trypsinised, resuspended in $10 \mathrm{ml}$ PBS and counted. They were then centrifuged (10 min, 2500 r.p.m. at $\left.4{ }^{\circ} \mathrm{C}\right)$, resuspended in PBS, fixed in $70 \%$ ice-cold ethanol and stored in $-20^{\circ} \mathrm{C}$ until staining. Cells were stained for at least $1 \mathrm{~h}$ in the dark with a solution containing $20 \mu \mathrm{g} \mathrm{ml}^{-1}$ propidium iodide (Sigma), $0.02 \mu \mathrm{g} \mathrm{ml}^{-1}$ RNAse and $1 \%$ Triton-X 100 (Sigma). The DNA content in the treated and mock-treated groups was measured by flow cytometry analysis using a FACSort flow cytometer (Becton Dickinson, San Jose, CA, USA); 15000 events were analysed for each sample. ModFit LT version 3.1 (Verity Software House Inc., Topsham, ME, USA) was used to analyse cell cycle distribution.

\section{Flowcytometry for apoptosis detection}

Cells were grown in T-75 flasks and treated with various concentrations of VN/66-1 and MS-275 for different times. Growth media were collected; cells were typsinzed, pelleted and washed with PBS. The Annexin V-FITC Apoptosis Detection Kit I was used to determine the number of early and late apoptotic/necrotic cells (BD Biosciences, San Jose, CA, USA). Cells were analysed using a FACSort flow cytometer as mentioned above; 10000 events were analysed. CellQuest Pro version 5.2.1 (BD Biosciences) was used to analyse the distribution of cells.

\section{Immunofluorescence}

PC-3 cells were grown on eight-chamber glass slides and treated with various agents for $24 \mathrm{~h}$. Immunofluorescence staining was carried out as described previously (Phatak et al, 2007). After fixing with methanol:acetone $(1: 1)$, cells were stained with $\gamma-\mathrm{H}_{2} \mathrm{AX}$ (Upstate, Waltham, MA, USA) and counterstained with 4',6-diamidino-2-phenylindole dihydrochloride (DAPI) (Sigma). Cells were viewed using a Zeiss Axiovert Fluorescent Microscope (Carl Zeiss, Gottingen, Germany). Images were processed using Openlab Volume Deconvolution software for Mac (Improvision, Lexington, MA, USA).

\section{Quantitative real-time PCR}

PC-3 cells were grown in T-75 flasks and were treated with various agents for $24 \mathrm{~h}$. Cells were then harvested and RNA 
isolated using the RNeasy Mini Kit (Qiagen Inc., Valencia, CA, USA). cDNA was synthesised using the ReactionReady First Strand cDNA Synthesis Kit (SuperArray Bioscience Corporation, Frederick, MD, USA) as directed by the manufacturer. The $\mathrm{RT}^{2}$ Real-Time SYBR Green PCR Master Mix and primers (retinoic acid receptor (RAR) $\beta 2$, cyclin D1 and $\beta$-actin) were also obtained from SuperArray. qRT-PCR was performed on a ABI 7900HT machine (Applied Biosystems, Foster City, CA, USA). The relative levels of $\operatorname{RAR} \beta 2$ and cyclin D1 expression were determined with reference to the internal $\beta$-actin control by calculating $2^{-\Delta \Delta \mathrm{CT}}$.

\section{Tumour xenograft studies}

All animal studies were performed according to the guidelines approved by the Institution of Animal Care and Use Committee (IACUC) of the University of Maryland School of Medicine. Male SCID mice 4-6 weeks of age (weighing 20-25 g) were obtained from the National Cancer Institute (Frederick, MD, USA). Mice were maintained in a controlled environment of light, humidity and temperature and were given food and water ad libitum. Subconfluent PC-3 cells were detached using citric saline, suspended in PBS, centrifuged and resuspended in Matrigel (BD Biosciences) $\left(10 \mathrm{mg} \mathrm{ml}^{-1}\right)$ at $5.0 \times 10^{7}$ cells per ml. Tumour cells were inoculated subcutaneously into each flank of the mice. Drug treatment was initiated when tumours were palpable $\left(\sim 75 \mathrm{~mm}^{3}\right)$. VN/66-1 and MS-275 were suspended in $0.3 \%$ hydroxypropyl cellulose in saline. VN/66-1 $\left(10 \mathrm{mg} \mathrm{kg}^{-1}\right)$ and MS-275 $\left(2.5 \mathrm{mg} \mathrm{kg}^{-1}\right)$ were administered daily (5 days per week) by subcutaneous injection. Tumour measurements were taken twice a week with a digital caliper and mice were weighed once a week. Tumour volume was calculated by the formula $(4 / 3$ $\left.\pi r_{1}^{2} \times r_{2}\right)$ with $r_{1}$ and $r_{2}$ being the larger and smaller radii, respectively.

\section{Western blot analysis}

For immunoblot detection of various proteins, PC-3 cells were cultured as described above in T75 flasks. Cells were treated with VN/66-1 or MS-275 and whole cell lysates were prepared using lysis buffer containing $0.1 \mathrm{M}$ Tris, $0.5 \%$ Triton X-100 and protease inhibitor. For detection of $\gamma-\mathrm{H} 2 \mathrm{AX}$ and Acetyl H3 and $\mathrm{H} 4$ (Upstate, Lake Placid, NY, USA), histones were extracted as described previously (Phatak et al, 2007). Protein content was determined using the Bradford Assay (Bio-Rad, Hercules, CA, USA). Protein was subjected to SDS-PAGE and transferred onto nitrocellulose membrane. Antibodies against PARP, RAR $\beta$ and E-cadherin were purchased from Santa Cruz Biotechnology (Santa Cruz, CA, USA). Antibodies against Bax, Bad, Bcl-2, cdc25C, p-cdc2 (Thr 14) and p-cdc2 (Tyr 15), and $\beta$-actin were purchased from Cell Signaling (Danvers, MA, USA) and p21 was purchased from Upstate (Millipore, Billerica, MA, USA). Membranes were then incubated with secondary antibody (Bio-Rad) at room temperature for $1 \mathrm{~h}$. Bands were visualised by chemiluminescence (Millipore). Protein expression was normalised to $\beta$-actin and densitometry was carried out using ImageQuant 5.0 (Molecular Dynamics, Sunnyvale, CA, USA).

\section{Statistical analysis}

All experiments were carried out in at least triplicates and are expressed as mean \pm s.e. where applicable. Treatments were compared to controls using the Students' $t$-test with either GraphPad Prism or Sigma Plot. Various treatment groups were compared using the analysis of variance (ANOVA). P-values less than 0.05 were considered to be statistically significant.

\section{RESULTS}

\section{Effect of VN/66-1 and MS-257 alone or in combination on PC-3 cell viability}

The effect of VN/66-1 and MS-275 on PC-3 cell viability was examined by the MTT assay (Figure 1B). VN/66-1 inhibited PC-3 cell viability with an $\mathrm{IC}_{50}$ of $2.19 \mu \mathrm{M}$ and MS-275 was found to have an $\mathrm{IC}_{50}$ of $0.18 \mu \mathrm{M}$. However, in the combination treatment, there was a striking shift in the dose-response curve when compared to VN/66-1 alone (Figure 1B). This was seen after various doses $(0.01-10 \mu \mathrm{M})$ of VN/66-1 were treated with a low dose of MS-275 $(0.1 \mu \mathrm{M}$, a dose that inhibited cell viability by $\sim 20 \%$, Figure $1 \mathrm{~B})$. $\mathrm{N}$-(2-aminophenyl)4-[ $\mathrm{N}$-(pyridine-3-yl-methoxy-carbonyl)aminomethyl]benzamide $(0.1 \mu \mathrm{M})$ significantly enhanced the antiproliferative activity of VN/66-1 by $>2000$-fold $\left(\mathrm{IC}_{50}\right.$ from $2.19 \mu \mathrm{M}$ to $<1.0 \mathrm{nM})$.

Since the simultaneous treatment was found to be effective, it was important to determine whether sequential treatment would have similar effects. For the sequential treatment, cells were treated with each compound for $48 \mathrm{~h}$. It was found that only the simultaneous treatment had a synergistic effect in inhibiting PC-3 cell viability as shown by a classical isobologram (Figure 1C). Synergism was further assessed by calculating the CI values. A $\mathrm{CI}<1$, indicative of synergism, was only found for the simultaneous treatment $(\mathrm{CI}=0.18)$, while the sequential treatments were found to be antagonistic ( $\mathrm{CI}=1.10$ for VN/66-1 first; and $\mathrm{CI}=1.72$ for MS-275 first) at the 75\% inhibition level (Table 1). Furthermore, only the simultaneous treatment had a synergistic effect at all three (50, 75 and 90\%) inhibition levels.

Based on these results, cells were treated at concentrations, which correspond to a 75\% level of inhibition ( $10 \mu \mathrm{M} \mathrm{VN} / 66-1$ and $5 \mu \mathrm{M}$ MS-275) for all subsequent experiments unless otherwise stated. Because the combination was found to be synergistic, these concentrations were halved for simultaneous treatments $(5 \mu \mathrm{M} \mathrm{VN} /$ $66-1+2.5 \mu \mathrm{M}$ MS-275). This concentration of VN/66-1 is biologically relevant, because it is well below the maximum plasma concentration $(26.9 \mu \mathrm{M})$, which was achieved in mice following a single subcutaneous administration of $10 \mathrm{mg} \mathrm{kg}^{-1}$ of VN/66-1 (Patel et al, 2007a). It should also be noted that these concentrations of MS-275 have been used previously for a similar study using PC-3 cells (Chen et al, 2005). Furthermore, it has been reported that MS-275 has an $\mathrm{IC}_{50}$ value of $4.8 \mu \mathrm{M}$ in inhibiting HDAC activity in nuclear extracts (Miller et al, 2003).

We also tested PC3-AR cells, PC-3 cells infected with the androgen receptor and C-81 cells (high passage LNCaP cells) (Igawa et al, 2002) to see if they responded to the same extent as the PC-3 cells. Since PC-3 cells are known to be AR-negative and clinically most prostate tumours express the AR, it was important to determine if the effects of the combination treatment were independent of $\mathrm{AR}$ status. We found that the $\mathrm{IC}_{50}$ for the combination of VN/66-1+MS-275 (various concentrations of $\mathrm{VN} / 661-1+0.1 \mu \mathrm{M}$ MS-275) in the PC3-AR cells was $370 \mathrm{nM}$ (dose-response curve not shown). Similar results were obtained with C-81 cells (data not shown). It is evident that the combination is effective independent of AR status of the PCa cells.

Table I Combination index values for the three drug combinations at 50,75 and $90 \%$ inhibition levels on PC-3 cell viability

\begin{tabular}{lccc}
\hline & \multicolumn{3}{c}{ Cl values } \\
\cline { 2 - 4 } Drug combination & $\mathbf{5 0 \%}$ & $\mathbf{7 5 \%}$ & $\mathbf{9 0 \%}$ \\
\hline $\mathrm{VN} / 66-1+\mathrm{MS}-275$ & 0.56 & 0.18 & 0.24 \\
$\mathrm{VN} / 66-1 \rightarrow \mathrm{MS}-275$ & 1.85 & 1.10 & 0.69 \\
$\mathrm{MS}-275 \rightarrow \mathrm{VN} / 66-1$ & 0.56 & 1.72 & 4.74 \\
\hline
\end{tabular}

Arrows indicate the sequence of treatment. 
PC-3 cell growth inhibition by VN/66-1 or MS-275 or their combination is independent of retinoid receptors

Previously we had shown that VN/66-1 does not bind to or cause transactivation of the RARs $(\alpha, \beta$ or $\gamma$ ) (Patel et al, 2007b). To further examine the role of the RARs in the mechanism of action of either VN/66-1 or MS-275, we tested the effect of these agents in combination with AGN193109, a pan-RAR antagonist (Agarwal et al, 1996). AGN193109 did not have any effect on $1 \mu \mathrm{M}$ of VN/66$1,0.1 \mu \mathrm{M}$ of MS-275 or the combination (Figure 1D). Thus, we conclude that neither VN/66-1 nor MS-275 require the RARs to exert their growth inhibitory effects. However, this is not to say that the RARs are not involved in the mechanism of action of these agents, it only shows that the RARs are not necessary. This complements findings reported for the most active metabolite of 4-HPR, 4-oxo-fenretinide (4-oxo-4-HPR) (Villani et al, 2006) and the unhydrolyzable fenretinide analog, 4-hydroxybenzylretinone (Anding et al, 2007). It is important to note that VN/66-1 is structurally similar to these RRMs.

\section{Effects of VN/66-1 and MS-275 on cell cycle and proliferation}

VN/66-1 and MS-275 alone as well as the combination were found to induce a strong $\mathrm{G} 2 / \mathrm{M}$ phase arrest of the cell cycle when compared to vehicle-treated cells (Figure 2A-D). Previously, studies have reported that HDACIs generally induce a G1 phase arrest at lower concentrations and a G2/M phase arrest at higher concentrations (Richon et al, 2000; Lindemann et al, 2004). We confirmed that the cells were indeed not arrested in G1 by looking at cyclin D1 mRNA levels by RT-PCR, a marker for G1 phase arrest. We found that cyclin D1 mRNA levels were not significantly altered after treatment with either of the agents or the combination (data not shown). Furthermore, an increase in $\mathrm{p} 21^{\mathrm{WAF} / \mathrm{CIP1}}$ (hereafter referred to as p21), the cyclin-dependent kinase inhibitor, was observed. This is especially important since p21 has been known to be involved in the ability of HDACIs to block proliferation (Acharya et al, 2005). p21 protein expression was found to be upregulated (9.25-fold) with MS-275 alone and even more (10-fold) in the combination of VN/66-1 and MS-275 (Figure 3D).

Both agents alone and the combination of VN/66-1 and MS-275 were found to be cytostatic and cytotoxic. A cell count over time revealed that while vehicle treated cells continued to proliferate, cells in the three treatment groups did not (Figure $3 \mathrm{~A}$ ). Furthermore, the number of late apoptotic and necrotic cells increased over time in the three treatment groups. Apoptotic control cells remained fairly constant until $72 \mathrm{~h}$ at which time these cells were most likely dying from depleted serum levels in the media (Figure 3B). This indicated that the cells were actually dying after treatment with VN/66-1 or MS-275 alone and with the combination of both agents. Taken together, these data suggest that that cell cycle arrest followed by apoptosis leads to the reduced PC-3 cell survival that was observed.

\section{Treatments with VN/66-1 or MS-275 or their combination reactivate RAR $\beta 2$}

Retinoic acid receptor- $\beta 2$, a known tumour suppressor gene, which has been shown to be silenced in PC-3 cells (Nakayama et al, 2001). $N$-(2-aminophenyl)4-[ $N$-(pyridine-3-yl-methoxy-carbonyl) aminomethyl]benzamide has previously been shown to reactivate $\operatorname{RAR} \beta 2$ in a variety of cell lines including prostate, renal carcinoma and breast cancer cells (Hess-Stumpp et al, 2007). We found that while MS-275 alone induced more than a three-fold increase in $\operatorname{RAR} \beta 2$ expression, the combination induced almost a seven-fold increase as determined by RT-PCR (Figure 3C).

\section{Effect of VN/66-1 and MS-275 on PC-3 cell protein expressions}

The levels of histone acetylation in PC-3 cells were determined after a $24 \mathrm{~h}$ treatment. Histones were isolated and western blot analysis revealed that there was an increase in acetylated histones 3 and 4 in the MS-275 and combination-treated cells (Figure 3D).
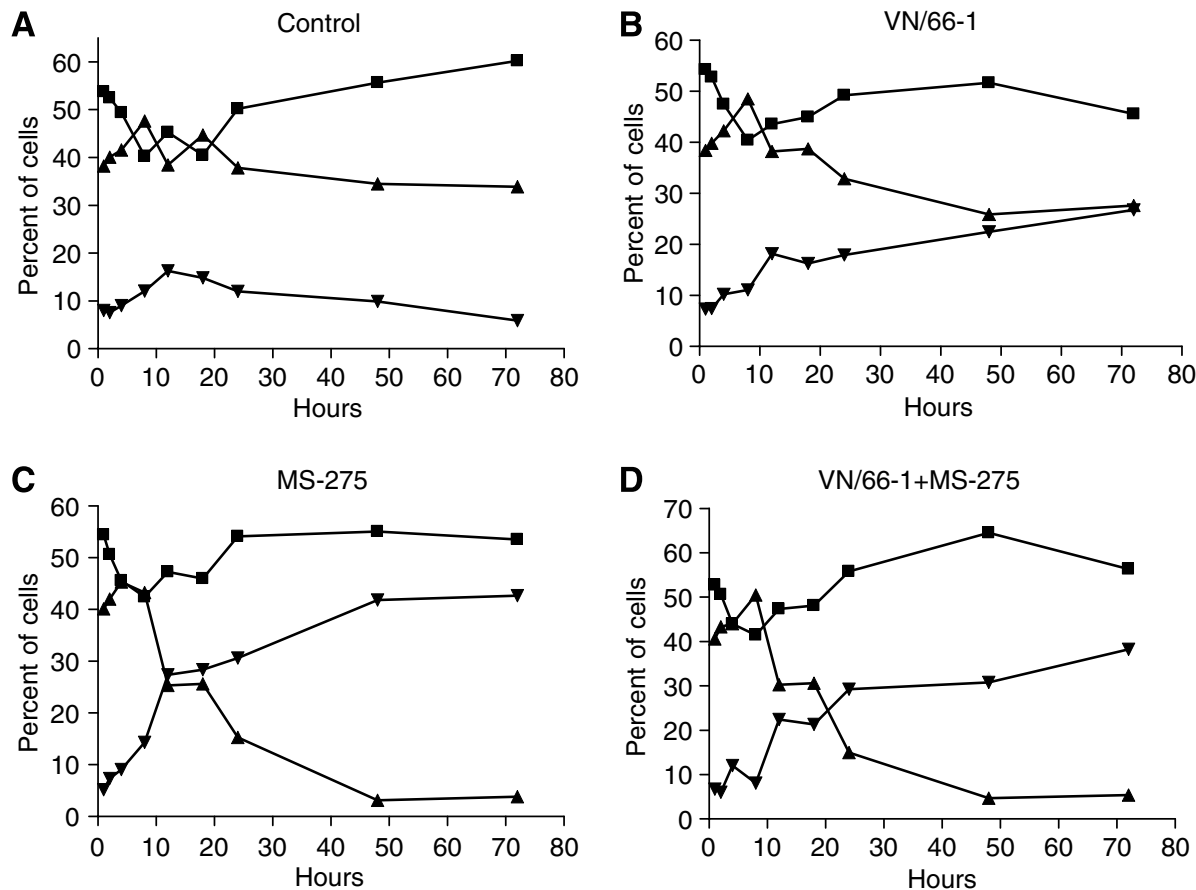

Figure 2 Percent of PC-3 cells in each phase of the cell cycle. (A) Control; (B) VN/66-I (I0 $\mu \mathrm{M})$; (C) MS-275 (5 $\mu \mathrm{M})$; (D) VN/66-I + MS-275 $(5+2.5 \mu \mathrm{M}$, respectively). represents the cells in the G0/GI phase; $\boldsymbol{\Delta}$ represents cells in the $\mathrm{S}$ phase; $\boldsymbol{\nabla}$ represents cells in the G2/M phase of the cell cycle. 

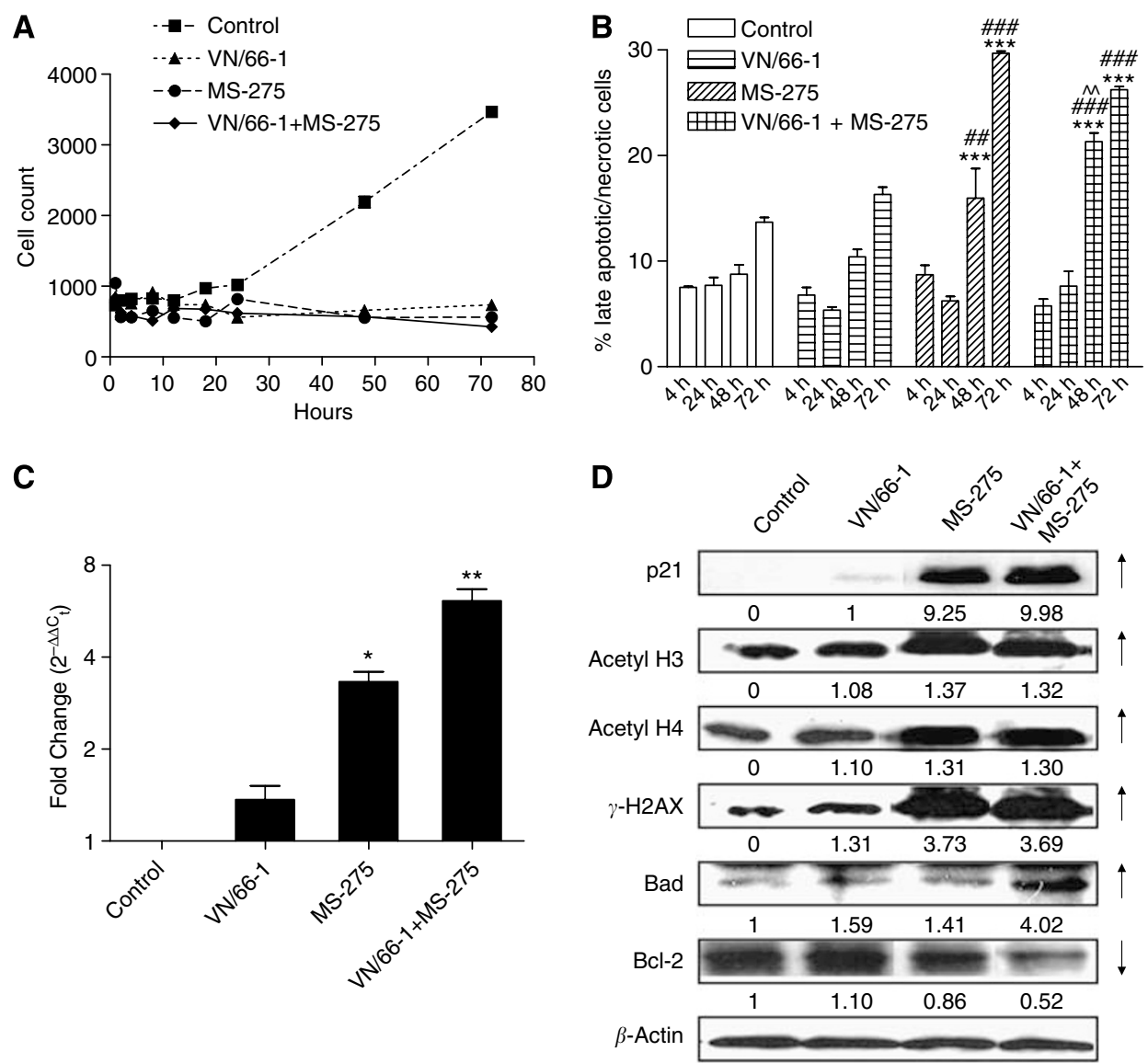

Figure 3 (A) Cell count over time after treatment of PC-3 cells. VN/66-I ( I $\mu \mathrm{M})$, MS-275 (5 $\mu \mathrm{M})$ and the combination VN/66-I + MS-275 (5 + $2.5 \mu \mathrm{M})$ were used, respectively. $P<0.00$ I for $18-72 \mathrm{~h}$ vs control (ANOVA) (two-way ANOVA was carried out and most time points were found to be significantly different for different treatments, but values are not reported here). (B) The percent of late apoptotic/necrotic cells as determined by Annexin $V$-FITC and PI positive staining by flow cytometry. **** $<<0.00$ I compared to control; ${ }^{\# \#} P<0.00$ I compared to VN/66-I; ${ }^{\# \#} P<0.0$ I compared to VN/66-I; ${ }^{\wedge} P<0.0$ I compared to MS-275 (ANOVA). (C) RAR $\beta$ mRNA expression after treatment of PC-3 cells for $24 \mathrm{~h}$. $* P<0.01$ and $* * P<0.001$ vs control and VN/66-I alone (t-test). Data are mean ( \pm s.e.) of three independent experiments $(\mathbf{A}-\mathbf{C})$. (D) Western blot analysis after treatment of PC-3 cells for $24 \mathrm{~h}$ (p2I, acetyl $\mathrm{H} 3, \mathrm{H} 4$ and $\gamma-\mathrm{H} 2 \mathrm{AX}$ ) or $4 \mathrm{~h}(\mathrm{Bad}, \mathrm{Bcl}-2)$. Blots are representative of three independent experiments. Note: the same concentrations as stated for (A) were used for subsequent experiments.

Increased acetylation of $\mathrm{H} 3$ and $\mathrm{H} 4$ is especially important because cells that are $\operatorname{RAR} \beta$ negative (LNCaP, PC-3 and DU-145 PCa cell lines) have been shown to be hypoacetylated at $\mathrm{H} 3$ and $\mathrm{H} 4$ (Nakayama et al, 2001). This is another reason why combining an HDACI with a RAMBA is especially important for PCa treatment. Furthermore, deacetylation of these two histones around the promoter region has also been implicated in the silencing or inactivation of p21 (Gui et al, 2004; Ocker and Schneider-Stock, 2007).

A general screen to determine whether apoptosis was occurring via the mitochondrial pathway revealed that Bad levels were increased and Bcl-2 levels were decreased in the combinationtreated group (Figure 3D). Furthermore, staining cells with Annexin V/FITC and PI revealed that there was a time-dependent increase in the number of early (Annexin V-FITC positive, PI negative; (data not shown)) and late (Annexin V-FITC and PI positive) apoptotic cells after treatment with $\mathrm{VN} / 66-1$ and/or MS-275 (Figure 3B).

\section{VN/66-1 in combination with MS-275 induces strong DNA damage}

The phosphorylation of histone variant $\mathrm{H} 2 \mathrm{AX}, \gamma-\mathrm{H} 2 \mathrm{AX}$ was observed by immunofluorescent staining of PC-3 cells after a
$24 \mathrm{~h}$ treatment with the agents. $\gamma-\mathrm{H} 2 \mathrm{AX}$, which is a maker for DNA damage, was found to be expressed in all three treatment groups, but strong foci were only seen in the combination group (Figure 4). When $\gamma$-H2AX-stained cells were overlaid with DAPI-stained cells, it was apparent that the nucleus was intact and the DNA damage was occurring within the nucleus. The occurrence of DNA damage was confirmed by western blot analysis with the $\gamma-\mathrm{H} 2 \mathrm{AX}$ antibody (Figure 3D).

The combination of VN/66-1 and MS-275 shows an inhibitory effect on $\mathrm{PC}-3$ prostate tumour growth in vivo

To demonstrate therapeutic activity of VN/66-1 + MS-275, an in vivo antitumour study was conducted. PC-3 xenografts were grown in male SCID mice and treated with $10 \mathrm{mg} \mathrm{kg}^{-1}$ of VN/66-1 or $2.5 \mathrm{mg} \mathrm{kg}^{-1}$ of MS-275 or the combination of the two (subcutaneous administration). An initial dose-response study was performed to determine which doses of VN/66-1 and MS-275 would be best for the study. Three doses each of VN/66-1 $(5,10$ and $\left.20 \mathrm{mg} \mathrm{kg}^{-1}\right)$ and MS-275 (5, 10 and $15 \mathrm{mg} \mathrm{kg}^{-1}$ ) were examined in a PC-3 xenograft model (data not shown). The purpose of the dose response study was to select a dose, which was not only effective in inhibiting tumour growth but also displayed minimal toxicity in the mice. Moderate weight loss was observed 

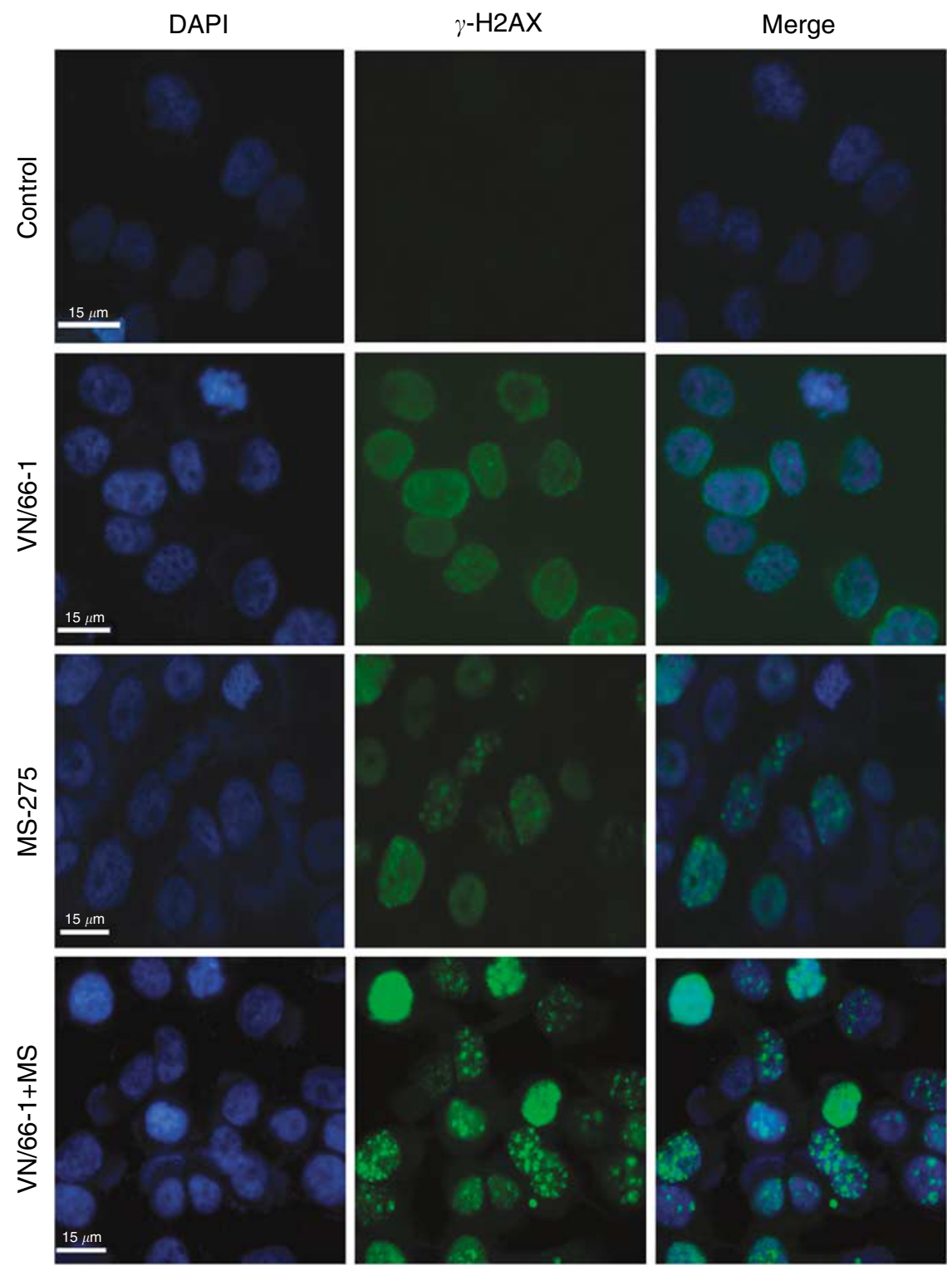

Figure 4 Immunocytochemistry performed with PC-3 cells after a $24 \mathrm{~h}$ treatment to determine the occurrence of DNA damage. Concentrations used are as follows: VN/66-I (I0 $\mu \mathrm{M}), \mathrm{MS}-275(5 \mu \mathrm{M})$ and the combination VN/66-I + MS-275 $(5+2.5 \mu \mathrm{M})$, respectively.

with the higher doses of MS-275; however, no other toxic events were noted with either compound. Based on the results that $5 \mathrm{mg} \mathrm{kg}^{-1}$ was very effective in inhibiting tumour growth, we decided to use even a lower dose for the combination study; hence, $2.5 \mathrm{mg} \mathrm{kg}^{-1}$ was administered for MS-275 alone in combination with $10 \mathrm{mg} \mathrm{kg}^{-1}$ of VN/66-1.

We found that the combination of VN/66-1 and MS-275 was the most efficacious and inhibited PC-3 tumour growth by more than $85 \%$ (Figure $5 \mathrm{~A}$ ). The mean change in tumour volume data corresponded well with the mean tumour weights for each group (Figure 5C). Furthermore, no overt weight loss was seen in any of the treatment groups (Figure 5B). Although it may appear that the combination group had lower mean body weights than the other groups, it is important to note that this group had the lowest body weights at the start of the treatment. A dotted line is drawn from $20 \mathrm{~g}$ on Figure $5 \mathrm{~B}$ to clarify this. These in vivo results confirm our in vitro results that VN/66-1 and MS-275 in combination inhibit cell and tumour growth more effectively than either of the agents alone.

\section{Effect of treatment on PC-3 tumour protein expressions}

Loss of E-cadherin, which is involved in adhesion between epithelial cells has been associated with tumour progression and metastasis (Mareel and Leroy, 2003). Thus, E-cadherin upregulation is often associated with increased differentiation of cancer cells. Immunoblot analysis with the tumour samples revealed that there was an increase in E-cadherin expression to some extent in the treatment groups (Figure 5C). Expression of p21 was also upregulated as was previously seen in whole cells. Since we had earlier demonstrated that apoptosis was taking place in vitro, we wanted to confirm if it was taking place in vivo. Thus, we examined the cleavage of PARP, and expression of Bax, Bad and Bcl-2. Although low levels of PARP cleavage was seen in the control tumours at a basal level, which is often associated with tumours, higher levels of the cleaved fragment $(89 \mathrm{kDa})$ were observed in the treatment groups. Bax and Bad levels, which are both proapoptotic proteins, were elevated in the combination groups. Bcl-2, an antiapoptotic protein was found to have decreased levels in 

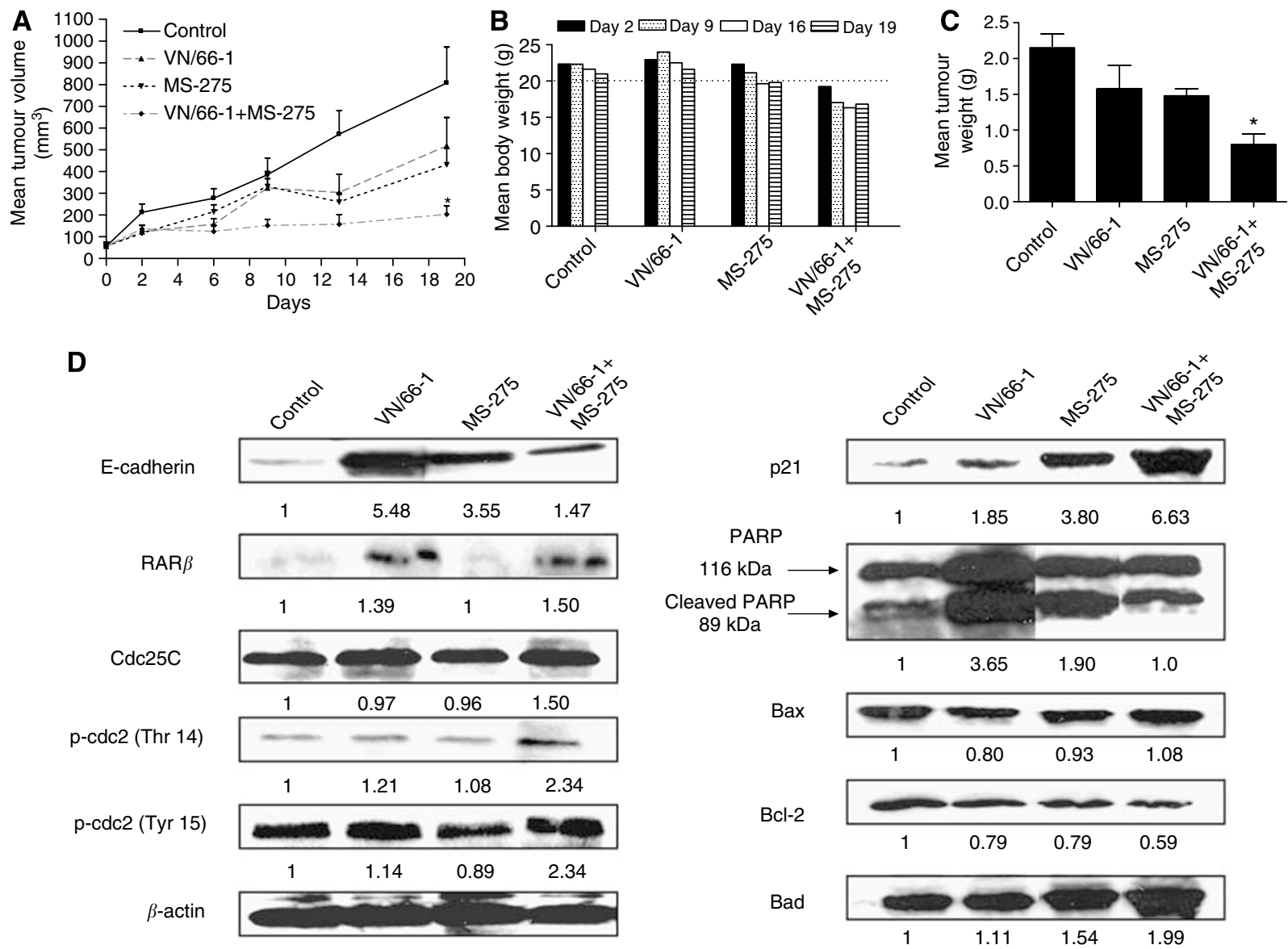

Figure 5 (A) The effect of VN/66-I $\left(10 \mathrm{mg} \mathrm{kg}^{-1}\right), \mathrm{MS}-275\left(2.5 \mathrm{mg} \mathrm{kg}^{-1}\right)$ and the combination $\left(10+2.5 \mathrm{mg} \mathrm{kg}^{-1}\right.$, respectively) in a PC-3 xenograft model in male SCID mice. Mice $(n=5)$ were injected subcutaneously QD, tumours were measured twice a week. Statistical significance was determined by the $t$-test. $* P<0.05$. Data are mean $( \pm$ s.e.) $(\mathbf{B})$ mean body weights. Mice were weighed once a week for the duration of the study. The dotted line at $20 \mathrm{~g}$ shows that the mice in the combination group weighed less than the mice in the other groups at the start of the study. (C) Mean tumour weights taken upon killing all mice and collecting tumours. $* P<0.05$. Data are mean $( \pm$ s.e.). (D) Western blot analysis of protein expression in $P C-3$ tumours taken from mice.

individual and combination groups (Figure 5D). These data support our proposed mechanism that apoptosis is taking place via the intrinsic pathway.

To further examine the occurrence of the G2/M phase arrest, the protein expression of various G2/M transition markers was assessed. It has been established that inhibitory phosphorylation of Cdc2 on Thr 14 and Tyr 15 causes the accumulation of inactive cyclin B1/Cdc2 complex (Mueller et al, 1995). Thus, we examined the expression of p-Thr 14 and p-Tyr 15 in the tumours. Both proteins showed increased levels in the combination treatment group. Cdc25C, a phosphatase that mediates the conversion of $\mathrm{Cdc} 2$ from an inactive to an active form was found to have unchanged levels in the tumours (Figure 5D). These data suggest that $\mathrm{G} 2 / \mathrm{M}$ arrest is taking place in the tumours as well.

Protein expression of tumour suppressor gene, $\operatorname{RAR} \beta$ was found to be increased in the tumours of the VN/66-1 and combinationtreated animals (Figure 5D). This is especially important because protein expression of RAR $\beta$ could not be detected in whole cells, which is why mRNA expression was determined by a more sensitive method in these cells. Thus, it is quite significant that $\operatorname{RAR} \beta$ protein expression could be detected in the tumours.

\section{DISCUSSION}

In the present study, we demonstrated, for the first time, a synergistic inhibitory effect of a RAMBA VN/66-1 and MS-275 on the growth of hormone-insensitive human PC-3 PCa cells and tumours. We also present data to suggest the mechanisms of action of these agents. A few studies have been carried out combining MS-275 and isomers of ATRA (9-CRA or 13-CRA) as recently reported in a review by HessStumpp et al (2007). Although these two compounds have exhibited additive effects with MS-275, the therapy may be problematic for chronic use because of potential development of resistance due to induction of ATRA metabolism CYP26 enzymes (Freemantle et al, 2003; Njar et al, 2006b). In contrast, the combination of VN/66-1 and MS-275 is unlikely to succumb to this potential side effect, because VN/66-1 is a potent RAMBA and does not induce CYP26 enzymes in cancer cells (Patel et al, 2004; Huynh et al, 2006). Additionally, we have shown that while ATRA causes alopecia, skin scaling and loss of body weight at relatively low doses, VN/66-1 does not exhibit these toxic events even at doses as high as $45.7 \mathrm{mg} \mathrm{kg}^{-1}$ day $^{-1}$ for 14 consecutive days in mice (Patel et al, 2007a).

In this study, we examined the combinatorial effects of VN/66-1 and MS-275 in hormone-refractory PC-3 cells. We observed that the two agents, when administered simultaneously, had a synergistic effect in inhibiting PC-3 cell growth. We also studied the effects of each sequential treatment, VN/66-1 first and then MS-275 first. Although the sequential treatments showed antagonistic effects, this is not the first time a sequential treatment with an HDACI has been found to be antagonistic, which was found to be due to conflicting signalling pathways (Kuefer et al, 2007). This portrays the importance of careful investigation into the effects of combination treatments and why it should not be assumed that, 
because two agents are effective as monotherapies, they will be effective in combination (Bevins and Zimmer, 2005; Hurtubise and Momparler, 2006).

We went on to show that both agents alone and in combination induced a G2/M phase arrest of the cell cycle in PC-3 cells. We also found that the combination was cytostatic as well as cytotoxic by blocking proliferation and inducing apoptosis. Together, these data suggest that cell cycle arrest followed by apoptosis leads to the reduced cell survival observed in the PC-3 cells. We propose that apoptosis is occurring via the mitochondrial pathway (intrinsic) based on the increased protein expression of Bad and decreased protein expression of Bcl-2. Retinoic acid receptor- $\beta 2$, a tumour suppressor gene silenced in the PC-3 cells, was found to be reactivated and had approximately a seven-fold increase in mRNA levels in the combination-treated cells. DNA damage was also found to take place rather strongly in the VN/66-1 + MS-275 group after a $24 \mathrm{~h}$ treatment. A marked increase in histone 3 and 4 acetylation was also observed after a $24 \mathrm{~h}$ treatment, as was increased protein expression of p21. Acetylation of these two histones can be directly linked to $\operatorname{RAR} \beta 2$ reactivation and $\mathrm{p} 21$ activation, since promoters of these genes have been found to be deacetylated at $\mathrm{H} 3$ and $\mathrm{H} 4$ (Lotan et al, 2000; Gui et al, 2004).

In vivo studies confirmed the in vitro results and showed that $\mathrm{VN} /$ $66-1\left(10 \mathrm{mg} \mathrm{kg}^{-1}\right)$ in combination with MS-275 $\left(2.5 \mathrm{mg} \mathrm{kg}^{-1}\right)$ is very effective in suppressing PC-3 tumour growth. It is important to point out that although the combination is additive in vivo at the doses used, higher doses would produce a synergistic effect. Furthermore, a slightly higher dose may completely prevent further growth of the initial tumours in the combination group. Even the doses used in this study are extremely effective in inhibiting tumour growth, moreover, no overt toxicity such as alopecia, skin scaling, loss of body weight or mortality was observed in the combination group. An increase in the protein expression of $\mathrm{Bad}$ and decrease in the expression of $\mathrm{Bcl}-2$ coupled with PARP cleavage suggests that the mechanism of apoptosis is via the intrinsic pathway. Differentiation was also observed by an increase in E-cadherin protein expression in the treatment groups. Retinoic acid receptor- $\beta$ and p21 protein expression were also upregulated in the combination treatment tumours. G2/M transition markers were examined in tumours to confirm the G2/M arrest seen in cells.

As summarised in Figure 6, the mechanism of action of the combination appears to be through the induction of DNA damage, which is known to activate p21. Activated p21 then inhibits the $\mathrm{Cdc} 2 /$ cyclin B complex, which is required for $\mathrm{G} 2 / \mathrm{M}$ progression (Weinberg, 2007). Furthermore, it has previously been shown that p21 and p53 are necessary to maintain a G2 arrest following DNA damage (Bunz et al, 1998). However, it is clear in this study that p21 induction is taking place in a p53-independent manner in PC-3 cells, since it is well established that this cell line carries mutated p53 (Horoszewicz et al, 1980). This accounts for the G2/M arrest, which is seen in the cells. Acetylation of histones $\mathrm{H} 3$ and $\mathrm{H} 4$ also contributes to $\mathrm{p} 21$ activation as well as to $\operatorname{RAR} \beta$ activation. This cell cycle block in conjunction with apoptosis and $\operatorname{RAR} \beta$ activation leads to eventual inhibition of PC-3 cell and tumour growth. The wide arrays of the anticancer properties of the two agents indicate that the biological mechanisms of actions of these agents are diverse thus making them more attractive for pre-clinical and clinical development for the treatment of PCa.

\section{REFERENCES}

Acharya MR, Sparreboom A, Venitz J, Figg WD (2005) Rational development of histone deacetylase inhibitors as anticancer agents: a review. Mol Pharmacol 68: 917-932

Agarwal C, Chandraratna RA, Johnson AT, Rorke EA, Eckert RL (1996) AGN193109 is a highly effective antagonist of retinoid action in human ectocervical epithelial cells. J Biol Chem 271: 12209-12212

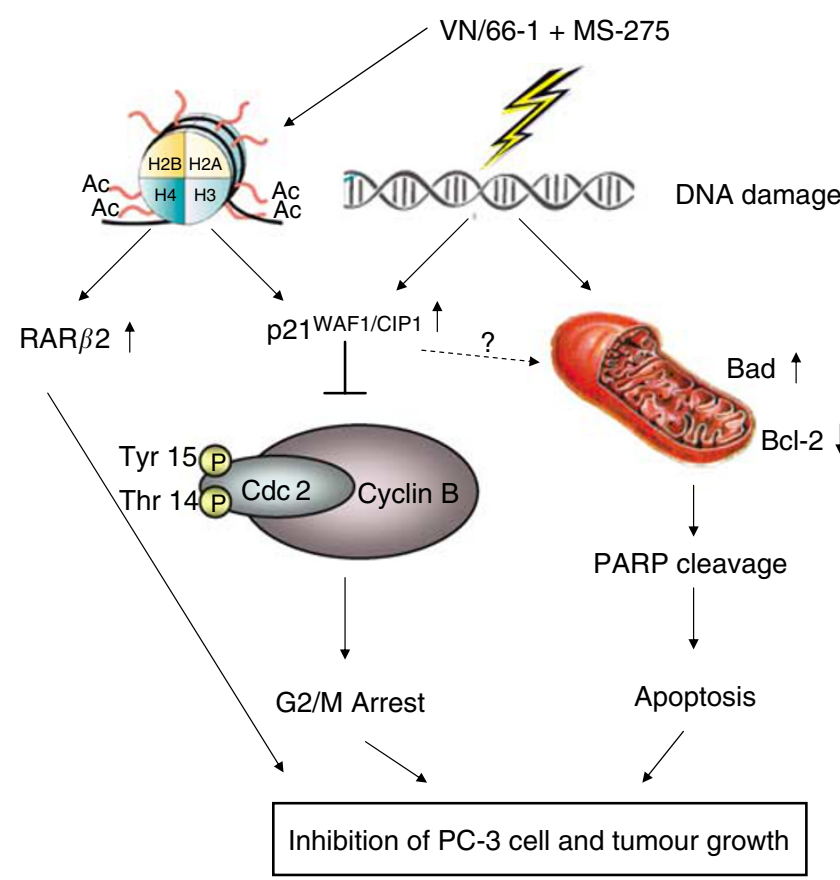

Figure 6 Schematic representation of the effect of VN/66-I + MS-275 on DNA damage-induced G2-M cell cycle arrest and apoptosis.

In conclusion, we have found a potent combination, which is effective against hormone-refractory PCa cells and tumours. This combination of RAMBA VN/66-1 and HDACI MS-275 is highly effective in inhibiting PC-3 cell and tumour growth. In the near future, we plan to repeat the in vivo study with oral dosing, since MS-275 is orally bioavailable and is a preferred route of administration (Hess-Stumpp et al, 2007). Additionally, we propose to further investigate the mechanism of induction of DNA damage. These are the first studies to specifically explore the anticancer activities and biological mechanisms of VN/66-1 in combination with MS-275 in PCa. On the basis of these profound results, further pre-clinical studies are warranted to develop the combination of VN/66-1 and MS-275 for the treatment of PCa.

\section{ACKNOWLEDGEMENTS}

This research was supported in part by grants from US National Institutes of Health and National Cancer Institute (CA117991) and US Department of Defense under the Peer Reviewed Medical Research Program (W81XWH-04-1-0101) to VCON. We thank these agencies for their generous support. Additionally, we thank Dr Angelika Burger, Dr Pornima Phatak and the University of Maryland Marlene and Stewart Greenebaum Cancer Center Translational Core Lab for the use of their fluorescence microscope and some antibodies. A preliminary report of this work was presented at the 98th American Association for Cancer Research Annual Meeting (2007).
Altucci L, Gronemeyer H (2001) The promise of retinoids to fight against cancer. Nat Rev Cancer 1: 181-193

Anding AL, Chapman JS, Barnett DW, Curley Jr RW, Clagett-Dame M (2007) The unhydrolyzable fenretinide analogue 4-hydroxybenzylretinone induces the proapoptotic genes GADD153 (CHOP) and Bcl-2-binding component 3 (PUMA) and apoptosis that is caspase- 
dependent and independent of the retinoic acid receptor. Cancer Res 67: $6270-6277$

Belosay A, Brodie AM, Njar VC (2006) Effects of novel retinoic acid metabolism blocking agent (VN/14-1) on letrozole-insensitive breast cancer cells. Cancer Res 66: $11485-11493$

Bevins RL, Zimmer SG (2005) It's about time: scheduling alters effect of histone deacetylase inhibitors on camptothecin-treated cells. Cancer Res 65: $6957-6966$

Bolden JE, Peart MJ, Johnstone RW (2006) Anticancer activities of histone deacetylase inhibitors. Nat Rev Drug Discov 5: 769-784

Bunz F, Dutriaux A, Lengauer C, Waldman T, Zhou S, Brown JP, Sedivy JM, Kinzler KW, Vogelstein B (1998) Requirement for p53 and p21 to sustain G2 arrest after DNA damage. Science 282: 1497-1501

Butler LM, Agus DB, Scher HI, Higgins B, Rose A, Cordon-Cardo C, Thaler HT, Rifkind RA, Marks PA, Richon VM (2000) Suberoylanilide hydroxamic acid, an inhibitor of histone deacetylase, suppresses the growth of prostate cancer cells in vitro and in vivo. Cancer Res 60: 5165-5170

Chen CS, Weng SC, Tseng PH, Lin HP, Chen CS (2005) Histone acetylationindependent effect of histone deacetylase inhibitors on Akt through the reshuffling of protein phosphatase 1 complexes. J Biol Chem 280: $38879-38887$

Chou TC, Tan QH, Sirotnak FM (1993) Quantitation of the synergistic interaction of edatrexate and cisplatin in vitro. Cancer Chemother Pharmacol 31: 259-264

Freemantle SJ, Spinella MJ, Dmitrovsky E (2003) Retinoids in cancer therapy and chemoprevention: promise meets resistance. Oncogene 22: $7305-7315$

Gediya LK, Chopra P, Purushottamachar P, Maheshwari N, Njar VC (2005) A new simple and high-yield synthesis of suberoylanilide hydroxamic acid and its inhibitory effect alone or in combination with retinoids on proliferation of human prostate cancer cells. J Med Chem 48: 5047-5051

Gu J, Zhao X, Spanjaard RA, Chen TC, Flanagan JN, Boosalis M, Perrine SP, Faller DV (2006) Histone deacetylase inhibitors sensitize human prostate cancer cell lines to growth inhibitory suppression and apoptosis by retinoids. J Cancer Mol 2: 25-36

Gui CY, Ngo L, Xu WS, Richon VM, Marks PA (2004) Histone deacetylase (HDAC) inhibitor activation of p21WAF1 involves changes in promoterassociated proteins, including HDAC1. Proc Natl Acad Sci USA 101: $1241-1246$

Hess-Stumpp H, Bracker TU, Henderson D, Politz O (2007) MS-275, a potent orally available inhibitor of histone deacetylases - the development of an anticancer agent. Int J Biochem Cell Biol 39: 1388- 1405

Horoszewicz JS, Leong SS, Chu TM, Wajsman ZL, Friedman M, Papsidero L, Kim U, Chai LS, Kakati S, Arya SK, Sandberg AA (1980) The LNCaP cell line - a new model for studies on human prostatic carcinoma. Prog Clin Biol Res 37: 115- 132

Hurtubise A, Momparler RL (2006) Effect of histone deacetylase inhibitor LAQ824 on antineoplastic action of 5-Aza-2'-deoxycytidine (decitabine) on human breast carcinoma cells. Cancer Chemother Pharmacol 58: 618-625

Huynh CK, Brodie AM, Njar VC (2006) Inhibitory effects of retinoic acid metabolism blocking agents (RAMBAs) on the growth of human prostate cancer cells and LNCaP prostate tumour xenografts in SCID mice. $\mathrm{Br} J$ Cancer 94: $513-523$

Igawa T, Lin FF, Lee MS, Karan D, Batra SK, Lin MF (2002) Establishment and characterization of androgen-independent human prostate cancer LNCaP cell model. Prostate 50: $222-235$

Insinga $\mathrm{A}$, Monestiroli $\mathrm{S}$, Ronzoni $\mathrm{S}$, Gelmetti $\mathrm{V}$, Marchesi $\mathrm{F}$, Viale $\mathrm{A}$ Altucci L, Nervi C, Minucci S, Pelicci PG (2005) Inhibitors of histone deacetylases induce tumor-selective apoptosis through activation of the death receptor pathway. Nat Med 11: 71-76

Ito K, Adcock IM (2002) Histone acetylation and histone deacetylation. Mol Biotechnol 20: 99-106

Jemal A, Siegel R, Ward E, Murray T, Xu J, Thun MJ (2007) Cancer statistics, 2007. CA Cancer J Clin 57: 43-66

Kuefer R, Genze F, Zugmaier W, Hautmann RE, Rinnab L, Gschwend JE, Angelmeier M, Estrada A, Buechele B (2007) Antagonistic effects of sodium butyrate and $\mathrm{N}$-(4-hydroxyphenyl)-retinamide on prostate cancer. Neoplasia 9: 246-253

Kuo MH, Allis CD (1998) Roles of histone acetyltransferases and deacetylases in gene regulation. Bioessays 20: 615-626

Lindemann RK, Gabrielli B, Johnstone RW (2004) Histone-deacetylase inhibitors for the treatment of cancer. Cell Cycle 3: 779-788

Lotan Y, Xu XC, Shalev M, Lotan R, Williams R, Wheeler TM, Thompson TC, Kadmon D (2000) Differential expression of nuclear retinoid receptors in normal and malignant prostates. J Clin Oncol 18: 116-121
Macaluso M, Giordano A (2004) How does DNA methylation mark the fate of cells? Tumori 90: $367-372$

Mareel M, Leroy A (2003) Clinical, cellular, and molecular aspects of cancer invasion. Physiol Rev 83: 337-376

Marks PA, Richon VM, Rifkind RA (2000) Histone deacetylase inhibitors: inducers of differentiation or apoptosis of transformed cells. J Natl Cancer Inst 92: 1210-1216

Miller TA, Witter DJ, Belvedere S (2003) Histone deacetylase inhibitors. J Med Chem 46: 5097-5116

Mueller PR, Coleman TR, Kumagai A, Dunphy WG (1995) Myt1: a membrane-associated inhibitory kinase that phosphorylates Cdc2 on both threonine-14 and tyrosine-15. Science 270: 86-90

Nakayama T, Watanabe M, Yamanaka M, Hirokawa Y, Suzuki H, Ito H, Yatani R, Shiraishi T (2001) The role of epigenetic modifications in retinoic acid receptor beta2 gene expression in human prostate cancers. Lab Invest 81: 1049-1057

Njar VC, Gediya L, Purushottamachar P, Chopra P, Belosay A, Patel JB (2006a) Retinoids in clinical use. Med Chem 2: $431-438$

Njar VC, Gediya L, Purushottamachar P, Chopra P, Vasaitis TS, Khandelwal A, Mehta J, Huynh C, Belosay A, Patel J (2006b) Retinoic acid metabolism blocking agents (RAMBAs) for treatment of cancer and dermatological diseases. Bioorg Med Chem 14: 4323-4340

Ocker M, Schneider-Stock R (2007) Histone deacetylase inhibitors: signalling towards p21cip1/waf1. Int J Biochem Cell Biol 39: 1367-1374

Patel JB, Huynh CK, Handratta VD, Gediya LK, Brodie AM, Goloubeva OG, Clement OO, Nanne IP, Soprano DR, Njar VC (2004) Novel retinoic acid metabolism blocking agents endowed with multiple biological activities are efficient growth inhibitors of human breast and prostate cancer cells in vitro and a human breast tumor xenograft in nude mice. J Med Chem 47: $6716-6729$

Patel JB, Khandelwal A, Chopra P, Handratta VD, Njar VC (2007a) Murine toxicology and pharmacokinetics of novel retinoic acid metabolism blocking agents. Cancer Chemother Pharmacol 60(6): 899-905

Patel JB, Mehta J, Belosay A, Sabnis G, Khandelwal A, Brodie AM, Soprano DR, Njar VC (2007b) Novel retinoic acid metabolism blocking agents have potent inhibitory activities on human breast cancer cells and tumour growth. $\mathrm{Br}$ J Cancer 96: $1204-1215$

Patra SK, Patra A, Dahiya R (2001) Histone deacetylase and DNA methyltransferase in human prostate cancer. Biochem Biophys Res Commun 287: $705-713$

Phatak P, Cookson JC, Dai F, Smith V, Gartenhaus RB, Stevens MF, Burger AM (2007) Telomere uncapping by the G-quadruplex ligand RHPS4 inhibits clonogenic tumour cell growth in vitro and in vivo consistent with a cancer stem cell targeting mechanism. Br J Cancer 96: $1223-1233$

Pili R, Kruszewski MP, Hager BW, Lantz J, Carducci MA (2001) Combination of phenylbutyrate and 13-cis retinoic acid inhibits prostate tumor growth and angiogenesis. Cancer Res 61: 1477-1485

Qian DZ, Ren M, Wei Y, Wang X, van de Geijn F, Rasmussen C, Nakanishi $\mathrm{O}$, Sacchi N, Pili R (2005) In vivo imaging of retinoic acid receptor beta2 transcriptional activation by the histone deacetylase inhibitor MS-275 in retinoid-resistant prostate cancer cells. Prostate 64: $20-28$

Qian DZ, Wei YF, Wang X, Kato Y, Cheng L, Pili R (2007) Antitumor activity of the histone deacetylase inhibitor MS-275 in prostate cancer models. Prostate 67: 1182-1193

Richon VM, Sandhoff TW, Rifkind RA, Marks PA (2000) Histone deacetylase inhibitor selectively induces p21WAF1 expression and gene-associated histone acetylation. Proc Natl Acad Sci USA 97: $10014-10019$

Robertson KD, Jones PA (2000) DNA methylation: past, present and future directions. Carcinogenesis 21: 461-467

Sonneveld E, van den Brink CE, van der Leede BM, Schulkes RK, Petkovich M, van der Burg B, van der Saag PT (1998) Human retinoic acid (RA) 4-hydroxylase (CYP26) is highly specific for all-trans-RA and can be induced through RA receptors in human breast and colon carcinoma cells. Cell Growth Differ 9: 629-637

Verheul HM, Qian DZ, Carducci MA, Pili R (2007) Sequence-dependent antitumor effects of differentiation agents in combination with cell cycledependent cytotoxic drugs. Cancer Chemother Pharmacol 60: 329-339

Villani MG, Appierto V, Cavadini E, Bettiga A, Prinetti A, Clagett-Dame M, Curley RW, Formelli F (2006) 4-oxo-fenretinide, a recently identified fenretinide metabolite, induces marked G2-M cell cycle arrest and apoptosis in fenretinide-sensitive and fenretinide-resistant cell lines. Cancer Res 66: 3238-3247

Weinberg RA (2007) The Biology of Cancer. New York: Garland Science 